\title{
Expression of target and reference genes in Daphnia magna exposed to ibuprofen
}

\author{
Lars-Henrik Heckmann"1, Richard Connon1, Thomas H Hutchinson², \\ Steve J Maund ${ }^{3}$, Richard M Sibly ${ }^{1}$ and Amanda Callaghan*1
}

Address: 'The University of Reading, School of Biological Sciences, Environmental Biology, PO Box 228, RG6 6AJ, UK, 2 AstraZeneca Global SHE, Brixham Environmental Laboratory, Devon, TQ5 8BA, UK and ${ }^{3}$ Syngenta Crop Protection AG, 4002 Basel, Switzerland

Email: Lars-Henrik Heckmann - l.heckmann@reading.ac.uk; Richard Connon - r.connon@reading.ac.uk; Thomas H Hutchinson - tom.hutchinson@astrazeneca.com; Steve J Maund - steve.maund@syngenta.com; Richard M Sibly - r.m.sibly@reading.ac.uk; Amanda Callaghan* - a.callaghan@reading.ac.uk

* Corresponding author

Published: 07 July 2006

BMC Genomics 2006, 7:175 doi:10.1/86/147|-2164-7-175
Received: 06 March 2006

Accepted: 07 July 2006

This article is available from: http://www.biomedcentral.com/I47I-2/64/7//75

(c) 2006 Heckmann et al; licensee BioMed Central Ltd.

This is an Open Access article distributed under the terms of the Creative Commons Attribution License (http://creativecommons.org/licenses/by/2.0), which permits unrestricted use, distribution, and reproduction in any medium, provided the original work is properly cited.

\begin{abstract}
Background: Transcriptomic techniques are now being applied in ecotoxicology and toxicology to measure the impact of stressors and develop understanding of mechanisms of toxicity. Microarray technology in particular offers the potential to measure thousands of gene responses simultaneously. However, it is important that microarrays responses should be validated, at least initially, using real-time quantitative polymerase chain reaction (QPCR). The accurate measurement of target gene expression requires normalisation to an invariant internal control e.g., total RNA or reference genes. Reference genes are preferable, as they control for variation inherent in the CDNA synthesis and PCR. However, reference gene expression can vary between tissues and experimental conditions, which makes it crucial to validate them prior to application.

Results: We evaluated 10 candidate reference genes for QPCR in Daphnia magna following a 24 $\mathrm{h}$ exposure to the non-steroidal anti-inflammatory drug (NSAID) ibuprofen (IB) at 0, 20, 40 and 80 $\mathrm{mg} \mathrm{IB} \mathrm{I}^{-1}$. Six of the 10 candidates appeared suitable for use as reference genes. As a robust approach, we used a combination normalisation factor (NF), calculated using the geNorm application, based on the geometric mean of three selected reference genes: glyceraldehyde-3phosphate dehydrogenase, ubiquitin conjugating enzyme and actin. The effects of normalisation are illustrated using as target gene leukotriene B4 I2-hydroxydehydrogenase (Ltb4dh), which was upregulated following $24 \mathrm{~h}$ exposure to $63-81 \mathrm{mg} \mathrm{IB} \mathrm{I}^{-1}$.

Conclusions: As anticipated, use of the NF clarified the response of $L t b 4 \mathrm{dh}$ in daphnids exposed to sublethal levels of ibuprofen. Our findings emphasise the importance in toxicogenomics of finding and applying invariant internal QPCR control(s) relevant to the study conditions.
\end{abstract}

\section{Background}

Toxicogenomics is an evolving discipline investigating stressor impact at the genome level [1]. Microarrays are state-of-the-art tools for global gene expression profiling of the response of an organism in a particular biological context. However, expression levels of key genes responding on the microarray need to be validated [2]. The preferred technique of validation is by real-time quantitative 
polymerase chain reaction (QPCR) [3,4]. Although QPCR is a fairly reliable technique, amplification can vary depending on factors such as RNA integrity, reverse transcriptase (RT) efficiencies, sample-to-sample variations in amplification efficiency, and variation in cDNA sample loading. Using the same sample sizes, assessing RNA integrity and equalising RNA concentrations prior to RT are some of the basic normalisation steps in QPCR [5]. However, normalisation to some internal control is essential for accurate QPCR to balance sample-to-sample variations within the RT and PCR reactions. Internal control is generally achieved using reference genes, also known as housekeeping genes.

Some of the most commonly used reference genes, such as $\beta$-actin and glyceraldehyde-3-phosphate dehydrogenase $(\mathrm{GAPDH})$, are historical carryovers from northern blotting, a "predecessor" of QPCR [5]. It is good practice to rigorously validate the suitability of these reference genes under the specific experimental condition to which they are applied [5-7]. Total RNA and rRNA have also been suggested as internal controls, although again differences between tissue, individuals and experimental conditions apply [8]. Moreover, using RNA as an internal control has the disadvantage of not controlling for variation inherent in the RT and PCR reactions [5]. None of these genes or RNA products are completely invariable, and thus each needs validation before use [5-7]. A further problem of using only one reference gene for normalisation, is that it theoretically should have been normalised itself prior to target gene normalisation [9]. Various methods have been proposed to overcome these problems. One involves the use of a normalisation factor (NF) based on the geometric mean of multiple carefully selected reference genes. This NF can be calculated by geNorm (see Vandesompele et al., 2002 [10] and the geNorm website [11]) or other freely available Excel (Microsoft) based software applications, e.g. BestKeeper [12] (see Pfaffl et al., 2004 [9]). Vandesompele et al., 2002 [10] recommend that NFs should be estimated from a minimum of three reference genes. The advantage of this approach is that it allows for the cumulative error of the entire process from RNA extraction to the QPCR.

Here we evaluate 10 candidate reference genes for QPCR in Daphnia magna following a $24 \mathrm{~h}$ exposure to the nonsteroidal anti-inflammatory drug (NSAID) ibuprofen (IB); 20, 40 and $80 \mathrm{mg} \mathrm{IB} \mathrm{l}^{-1}$. This concentration range represents a sublethal exposure based on our earlier work showing that the effect concentration needed to immobilise $50 \%\left(\mathrm{EC}_{50}\right)$ of the exposed individuals was $107.7 \mathrm{mg}$ IB $\mathrm{l}^{-1}$ following $48 \mathrm{~h} \mathrm{[13].} \mathrm{The} \mathrm{tested} \mathrm{candidate} \mathrm{reference}$ genes were chosen to cover a range of gene ontologies (Table 1, Methods), but mostly representing what may be considered as classical reference genes such as actin and GAPDH [6].

We use the geNorm algorithm [10] to estimate the variability of the reference genes, and to discover an optimal normalisation factor $(N F)$, based on the geometric mean of three of them. geNorm estimates reference gene variability by calculating an expression level ratio for any two candidate reference genes. The variation between the expression ratios is then used as an inverse measure to estimate the variability of the analysed reference genes (please see Methods or Vandesompele et al., (2002) [10] for further information). The approach is illustrated using as target gene the D. magna ortholog of leukotriene B4 12hydroxydehydrogenase (Ltb4dh), which was identified as being up-regulated in a suppressive subtractive hybridisation following $24 \mathrm{~h}$ exposure to 63-81 mg IB $\mathrm{l}^{-1}$ [13]. $L t b 4 d h$ is of special interest because NSAIDs are known to inhibit the mammalian biosynthesis of various eicosanoids (e.g. prostaglandins, epoxyeicosatrienoic acids and leukotriene) that play important regulatory and signalling functions, for instance regulation of ion flux $[14,15]$. As anticipated, use of the NF clarified the response of $L t b 4 d h$ to ibuprofen.

\section{Results \\ Water chemistry and quantification of ibuprofen}

The chemical parameters $\mathrm{pH}$ and conductivity remained stable throughout the exposure, ranging between 7.8-7.9 and $422-452 \mu \mathrm{S} \mathrm{cm}-1$, respectively. Water temperatures ranged from 20.8 to $21.0^{\circ} \mathrm{C}$. Ibuprofen-sodium increased measured pH by approximately $9 \%$ and conductivity by approximately $7 \%$ in the highest treatment ( $80 \mathrm{mg} \mathrm{IB} \mathrm{l}^{-1}$ ) compared with the control (data not shown).

Quantification of IB revealed that nominal concentrations were within $\pm 10 \%$ of the measured concentration; except for $20 \mathrm{mg} \mathrm{IB} \mathrm{l}^{-1}$ replicate three that was $10.6 \%$ lower than the nominal (data not shown). No mortality was observed in D. magna in any of the treatments following exposure.

\section{Relative expression and variability of candidate reference genes}

Relative gene expression was estimated using DART-PCR (see Methods). There was a significant $(p<0.05)$ downregulation of $A t b$ and $C y p$ at $80 \mathrm{mg} \mathrm{IB} \mathrm{l}^{-1}$ compared with the control (Table 2). The eight candidate reference genes unaffected by the IB treatment were analysed by geNorm (see Methods) ranking the least variable genes as; $U B C=$ GAPDH $<$ Act $<W A R S<S D H<T B P<18 S<28 S$ (Table 2). Subsequently, geNorm was applied to estimate seven normalisation factors, $N F_{2}$ to $N F_{8}$, based on the geometric mean of the relative expression of the included reference genes. The geNorm algorithm allocates the two least vari- 
Table I: Candidate reference genes and target gene investigated

\begin{tabular}{|c|c|c|c|c|c|c|c|}
\hline Gene name & Symbol & $\begin{array}{c}\text { GenBank } \\
\text { accession no. }\end{array}$ & $\begin{array}{l}\text { wFleaBase } \\
\text { EST no. }\end{array}$ & Gene Ontologya & Forward primer (5'-3') & Reverse primer (5'-3') & $\begin{array}{l}\text { Amplicon } \\
\text { size (bp) }\end{array}$ \\
\hline Actin & Act & A) 292554 & & $\begin{array}{l}\text { Structural constituent of cytoskeleton (F) } \\
\text { GO:0005200 }\end{array}$ & $\begin{array}{l}\text { CCA CAC TGT CCC CAT } \\
\text { TTA TGA A }\end{array}$ & $\begin{array}{l}\text { CGC GAC CAG CCA AAT } \\
\text { CC }\end{array}$ & 71 \\
\hline Alpha-tubulin & Atb & & WFes0007807 & Microtubule (C) GO:0005874 & $\begin{array}{l}\text { TGG AGG TGG TGA CGA } \\
\text { CT }\end{array}$ & $\begin{array}{l}\text { CCA AGT CGA CAA AGA } \\
\text { CAG CA }\end{array}$ & 89 \\
\hline Cyclophilin & Сур & & WFes00I 2034 & Protein folding (P) GO:0006457 & $\begin{array}{l}\text { GAC TTT CCA CCA GTG } \\
\text { CCA TT }\end{array}$ & $\begin{array}{l}\text { AAC TTT CCA TCG CAT } \\
\text { CAT CC }\end{array}$ & 78 \\
\hline $\begin{array}{l}\text { Glyceraldehyde-3- phosphate } \\
\text { dehydrogenase }\end{array}$ & GAPDH & A]292555 & & Glycolysis (P) GO:0006096 & $\begin{array}{l}\text { GGC AAG CTA GTT GTC } \\
\text { AAT GG }\end{array}$ & $\begin{array}{l}\text { TAT TCA GCT CCA GCA } \\
\text { GTT CC }\end{array}$ & 89 \\
\hline Succinate dehydrogenase & SDH & & WFes0009191 & Tricarboxylic acid cycle (P) GO:0006099 & $\begin{array}{l}\text { TGC CAT TTA GTC GCA } \\
\text { CTC AG }\end{array}$ & $\begin{array}{l}\text { GTG AGC TTG TCC TCC } \\
\text { TTT GC }\end{array}$ & 89 \\
\hline TATA-box binding protein & TBP & & WFes0002485 & Transcription initiation $(\mathrm{P}) \mathrm{GO} 00006367$ & $\begin{array}{l}\text { GCA GGG AAG TTT AGT } \\
\text { TTC TGG A }\end{array}$ & $\begin{array}{l}\text { TGG TAT GCA CAG GAG } \\
\text { CAA AG }\end{array}$ & 88 \\
\hline Tryptophanyl- tRNA synthetase & WARS & & WFes0003968 & $\begin{array}{l}\text { Tryptophanyl-tRNA ligase activity (F) } \\
\text { GO:0004830 }\end{array}$ & $\begin{array}{l}\text { GCA CTG TGA TCA GCT } \\
\text { CTT GC }\end{array}$ & $\begin{array}{l}\text { TTT CGA TTG GAG GAA } \\
\text { ATT CG }\end{array}$ & 82 \\
\hline Ubiquitin Conjugating Enzyme & $U B C$ & & WFes0004602 & $\begin{array}{l}\text { Ubiquitin-dependent protein catabolism (P) } \\
\text { GO:00065II }\end{array}$ & $\begin{array}{l}\text { TCA CCT GCA CTC ACC } \\
\text { ATT TC }\end{array}$ & $\begin{array}{l}\text { AAT CTC CGG AAC CAA } \\
\text { AGG AT }\end{array}$ & 90 \\
\hline I8S ribosomal RNA & 185 & AF070104 & & Protein biosynthesis (P) GO:00064I2 & $\begin{array}{l}\text { CGC TCT GAA TCA AGG } \\
\text { GTG TT }\end{array}$ & $\begin{array}{l}\text { TGT CCG ACC GTG AAG } \\
\text { AGA GT }\end{array}$ & 77 \\
\hline $28 \mathrm{~S}$ ribosomal $R N A$ & 285 & AF532883 & & Protein biosynthesis (P) GO:0006412 & $\begin{array}{l}\text { GAG GCG CAA TGA AAG } \\
\text { TGA AG }\end{array}$ & $\begin{array}{l}\text { TGT TCG AGA CGG GAT } \\
\text { CA }\end{array}$ & 70 \\
\hline $\begin{array}{l}\text { Leukotriene B4 I 2-hydroxy- } \\
\text { dehydrogenase }^{\mathrm{b}}\end{array}$ & $L t b 4 d h$ & DY242190 & & Response to toxin (P) GO:0009636 & $\begin{array}{l}\text { AAC CTA CAC CGA GGG } \\
\text { TTT CG }\end{array}$ & $\begin{array}{l}\text { TCC AAC ATT AAC GCC } \\
\text { ATT AAG C }\end{array}$ & 70 \\
\hline
\end{tabular}

aSeveral of the candidate reference genes are classified within multiple biological processes $(\mathrm{P})$, molecular functions $(\mathrm{F})$ or associated with one or more cellular components $(\mathrm{C})$. A biological function, accompanied by a GO number, has been listed here for each gene (for more information visit http://www.geneontology.org/).

bTarget gene also known as 15-oxoprostaglandin 13-reductase or more generally as NADP(H)-dependent alkenal/one oxidoreductase 
Table 2: Relative gene expression and variability of candidate reference genes

\begin{tabular}{|c|c|c|c|c|c|c|}
\hline \multirow[b]{2}{*}{ Gene } & \multicolumn{4}{|c|}{ Relative expression ${ }^{a}$} & \multirow[b]{2}{*}{ Gene variability ${ }^{b}$} & \multirow[b]{2}{*}{ Amplification efficiency (E) } \\
\hline & Control & $20 \mathrm{mg} \mathrm{IB} \mathrm{I}^{-1}$ & $40 \mathrm{mg} \mathrm{IB} \mathrm{I}^{-1}$ & 80 mg IB I-1 & & \\
\hline Act & $1.000 \pm 0.078$ & $0.963 \pm 0.035$ & $1.030 \pm 0.044$ & $1.001 \pm 0.040$ & 0.119 & $0.795 \pm 0.066$ \\
\hline Atb & $1.000 \pm 0.129$ & $0.896 \pm 0.126$ & $0.885 \pm 0.095$ & $0.613 \pm 0.045^{c}$ & - & $1.010 \pm 0.016$ \\
\hline Сур & $1.000 \pm 0.040$ & $0.949 \pm 0.103$ & $0.900 \pm 0.015$ & $0.817 \pm 0.067$ & - & $1.038 \pm 0.016$ \\
\hline GAPDH & $1.000 \pm 0.093$ & $0.914 \pm 0.059$ & $0.919 \pm 0.047$ & $0.879 \pm 0.067$ & 0.098 & $0.946 \pm 0.029$ \\
\hline SDH & $1.000 \pm 0.145$ & $0.889 \pm 0.170$ & $0.950 \pm 0.180$ & $1.027 \pm 0.026$ & 0.160 & $0.992 \pm 0.015$ \\
\hline$T B P$ & $1.000 \pm 0.096$ & $0.786 \pm 0.176$ & $0.788 \pm 0.153$ & $1.038 \pm 0.084$ & 0.192 & $0.925 \pm 0.016$ \\
\hline WARS & $1.000 \pm 0.117$ & $0.954 \pm 0.098$ & $0.906 \pm 0.060$ & $0.955 \pm 0.081$ & 0.136 & $0.922 \pm 0.064$ \\
\hline UBC & $1.000 \pm 0.040$ & $0.995 \pm 0.095$ & $1.024 \pm 0.016$ & $0.888 \pm 0.097$ & 0.098 & $1.034 \pm 0.013$ \\
\hline 185 & $1.000 \pm 0.279$ & $2.096 \pm 1.074$ & $2.506 \pm 1.640$ & $2.204 \pm 0.910$ & 0.430 & $0.853 \pm 0.089$ \\
\hline 285 & $1.000 \pm 0.261$ & $1.247 \pm 0.445$ & $1.410 \pm 0.560$ & $1.457 \pm 0.616$ & 0.313 & $0.846 \pm 0.020$ \\
\hline
\end{tabular}

Gene name abbreviations as Table I.

aValues are mean \pm SD (IB refers to ibuprofen). Expression levels are displayed relative to the mean control level.

bGene variability is estimated by geNorm as the variation (SD) of a given reference gene relative to the remaining reference genes (Atb and Cyp are not included in the analysis as they are significantly down-regulated by IB).

cHighest treatment $\left(80 \mathrm{mg} \mid \mathrm{BB} \mathrm{I}^{-1}\right)$ significantly different from any other treatment $(p<0.05)$.

dHighest treatment $\left(80 \mathrm{mg} \mathrm{IB}^{-1}\right)$ significantly different from control $(p<0.05)$.

able genes, here GAPDH and $U B C$, to $N F_{2}$. Then the sequential $\mathrm{NF}_{3}$ was based on the genes from $\mathrm{NF}_{2}$ and the third least variable gene Act, and so on.

\section{Variability of normalisation factors}

Pairwise comparisons of sequential normalisation factors computed by geNorm revealed a similar level of variability between $N F_{2}$ vs. $N F_{3}, N F_{3}$ vs. $N F_{4}, N F_{4}$ vs. $N F_{5}$ and $N F_{5}$ vs. $\mathrm{NF}_{6}$ (Fig. 1). This suggests that the use of either of these $N F s$ as internal control would be valid. But pairwise comparisons of $N F_{6}$ vs. $N F_{7}$ and $N F_{7}$ vs. $N F_{8^{\prime}}\left(28 S\left(N F_{7}\right)\right.$ and $18 S\left(\mathrm{NF}_{8}\right)$ ), more than doubled the variability (Fig. 1). Vandesompele et al., 2002 [10] recommend using as few reference genes as feasible, but a minimum of three. Thus, although it gave a similar variability to other combina-

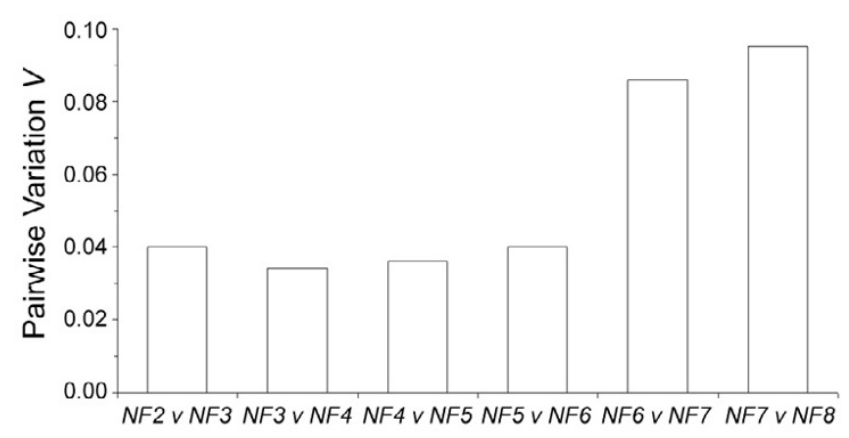

\section{Figure I}

Pairwise variation of sequential normalisation factors $\left(N F_{n}\right.$ vs. $N F_{n+1}$ ) estimated by geNorm. $N F_{2}$ is based on the geometric mean of GAPDH and UBC; $N F_{3}$ is $N F_{2}$ and $A c t$; $\mathrm{NF}_{4}$ is $N F_{3}$ and WARS; $N F_{5}$ is $N F_{4}$ and $\mathrm{SDH} ; \mathrm{NF}_{6}$ is $N F_{5}$ and $T B P$; $N F_{7}$ is $N F_{6}$ and $28 S ; N F_{8}$ is $N F_{7}$ and $18 S$ (gene name abbreviations as Table I). tions, we chose $\mathrm{NF}_{3}$, (GAPDH, UBC and Act) since it gave an optimal NF with a low level of variation using the lowest possible number of reference genes.

\section{Relative expression of reference genes following normalisation}

There is a circular problem with normalising a target gene with reference genes that should be normalised themselves prior to target gene normalisation [9]. Thus, in addition to normalising the target gene, we also normalised all 10 reference genes by $N F_{3}$. Atb had the same significant $(p<0.05)$ differences as prior to normalisation, and should therefore be regarded as a target gene. None of the other reference genes, including $C y p$, were significantly $(p>0.05)$ affected by IB following normalisation (data not shown).

\section{Relative expression of the target gene Ltb4dh following normalisation}

Without normalisation, the target gene $L t b 4 d h$ was significantly $(p<0.05)$ up-regulated at $80 \mathrm{mg} \mathrm{IB} \mathrm{l}^{-1}$ compared with any of the other treatment groups having a 3.24-fold higher expression than the control (Fig. 2). The relative expression of $L t b 4 d h$ followed a significant $(p<0.05)$ dose-dependent relationship (data not shown). Normalisation with $\mathrm{NF}_{3}$ produced a similar expression (Fig. 2). The relative expression of $L t b 4 d h$ was normalised individually by each of the 10 candidate reference genes and by $\mathrm{NF}_{3}$ to assess how their variability influenced target gene expression. Overall, the mean fold difference in relative expression between $80 \mathrm{mg} \mathrm{IB} \mathrm{l}^{-1}$ and the control was 3.34 $\pm 0.85 \mathrm{SD}$ ranging from 1.66 (18S) to 5.15 (Atb) (Fig. 3). Target gene expression normalised to any of the reference genes was compared to normalisation with $\mathrm{NF}_{3}$ revealing that there was a significant $(p<0.05)$ difference within the 


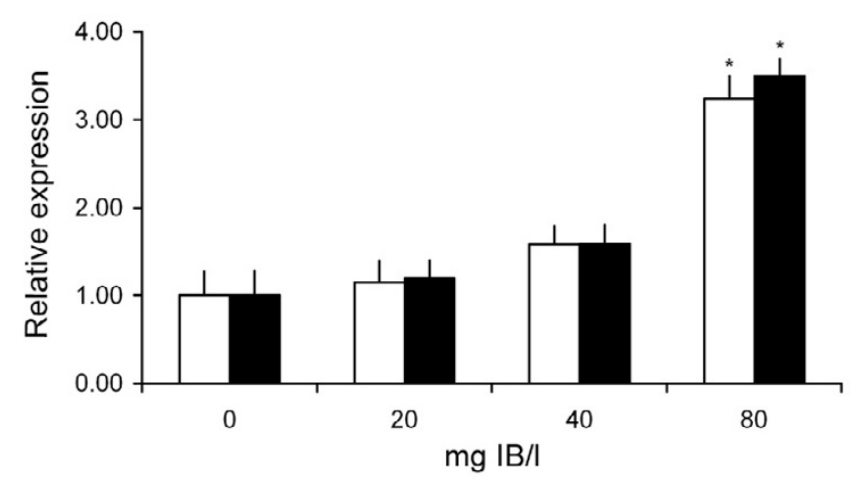

Figure 2

Relative gene expression of target gene Ltb4dh in Daphnia magna following a $\mathbf{2 4}$ h exposure to ibuprofen. Mean relative expression $(n=3) \pm$ SD of target gene Ltb4dh (amplification efficiency $E=1.060 \pm 0.042$ ) without normalisation (white bars) or with normalisation (black bars) to normalisation factor $\mathrm{NF}_{3}$ based on the geometric mean of Act, GAPDH and UBC (gene name abbreviations as Table I). Expression levels are displayed relative to the mean control level. An asterisk $(*)$ indicates a significant difference $(p<$ 0.05 ) between the highest treatment and any other treatment.

$80 \mathrm{mg} \mathrm{IB} \mathrm{l}^{-1}$ treatment between normalisation of $L t b 4 \mathrm{dh}$ to $A t b$ and Cyp respectively, and $L t b 4 d h$ normalised to $N F_{3}$ (Fig. 3). Although not significant ( $p>0.05)$, normalisation of $L t b 4 d h$ to either $18 S$ or $28 S$ caused a large increase in the variation of target gene expression in any of the IB treatments (Fig. 3). Both rRNA genes reduced significant differences observed in $L t b 4 d h$, with or without normalisation to $\mathrm{NF}_{3}$ (data not shown).

\section{Discussion}

We investigated the variability of 10 candidate reference genes in D. magna following a $24 \mathrm{~h}$ exposure to IB to discover the least variable internal control(s) for QPCR normalisation. A comparison of the reference genes, using the geNorm software, ranked the least variable genes as; UBC $=G A P D H<A c t<W A R S<S D H<T B P<18 S<28 S$. Atb and Cyp were not included in the geNorm analysis as they were down-regulated by IB. Furthermore, geNorm identified the optimal normalisation factor as $\mathrm{NF}_{3}$ based on the geometric mean expression of $U B C, G A P D H$ and Act. This NF was based on the lowest recommended number of reference genes with the lowest level of variation [10]. The response to IB of an example target gene, $L t b 4 d h$, was little changed by application of $\mathrm{NF}_{3}$ (Fig. 2), although at the highest concentration of IB, there was a slight increase in the response, and a diminution of the variation between replicates. Such reduction in the variation between replicates is exactly what one hopes to achieve through normalisation.
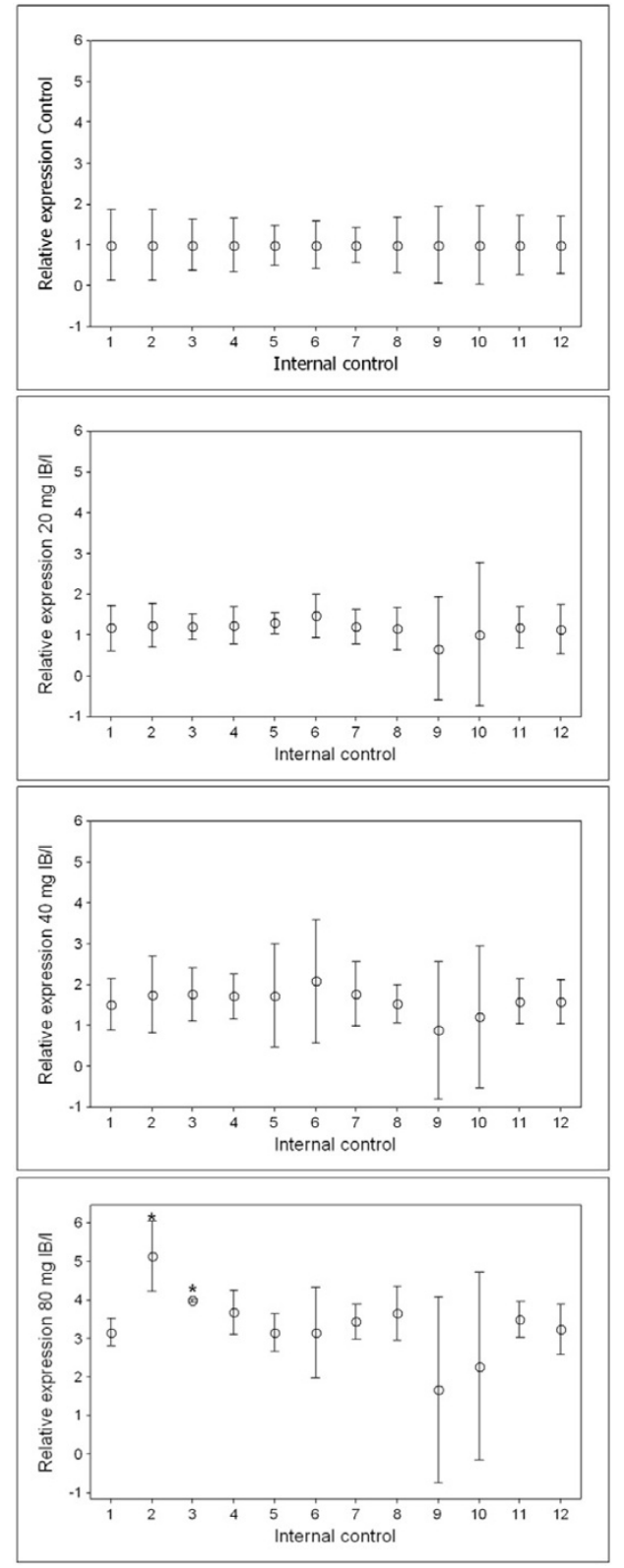

Figure 3

Relative gene expression of target gene Ltb4dh in Daphnia magna following a $\mathbf{2 4}$ h exposure to ibuprofen. Mean relative expression $(n=3) \pm$ SD of Ltb4dh following normalisation to 10 candidate reference genes and a normalisation factor (NF). Expression levels are displayed relative to the mean control level. For comparison, the normalised relative expression of $L t b 4 d h$ is displayed by treatment group. Relative expression of Ltb4dh normalised to: Act (I); Atb (2); Cyp (3); GAPDH (4); SDH (5); TBP (6); WARS (7); UBC (8); I $8 \mathrm{~S}(9) ; 28 \mathrm{~S}$ ( I0); $\mathrm{NF}_{3}$ based on the geometric mean of Act, GAPDH and UBC (I I); and Ltb4dh without normalisation (I2) (gene name abbreviations as Table I). An asterisk (*) indicates a significant difference $(p<0.05)$ from $L$ tb4dh normalised by $\mathrm{NF}_{3}$. 
QPCR confirmed that $L t b 4 d h$ was up-regulated following exposure to IB [13]. NSAIDs are known to inhibit the biosynthesis of various eicosanoids that play important regulatory and signalling functions, e.g. regulation of ion flux. In mammals, $L t b 4 d h$ is involved in the metabolism of leukotriene $\mathrm{B}_{4}$ an eicosanoid that is formed in the lipoxygenase pathway [15]. There is evidence of eicosanoid pathways in invertebrates being similar to the mammalian pathways [16]. Further experimentation, involving a global expression profile based on cDNA microarrays, is underway to support this hypothesis and reveal the overall molecular stress response of D. magna to IB. To our knowledge, this is one of the first genomic studies to look at the impact of a NSAID on an aquatic invertebrate. The only non-mammalian studies are on yeast Saccharomyces cerevisiae [17], a Drosophila cell line [18] and Bacillus megaterium [19].

Following normalisation to $\mathrm{NF}_{3}$ it transpired that $A t b$, assayed as a candidate reference gene, was affected by IB, and so should be regarded as an IB target gene. In a review on the molecular mechanism of NSAIDs in mammals, Tarnawski and Jones, 2003 [20] reveal that it is likely that NSAIDs exert many inhibitory effects, one of which is the inhibition of cell division. The observed suppression of $A t b$ following exposure to IB could be linked to this, since alpha-tubulin helps form microtubules that are involved in cell division, cell structure, and transportation of vesicles and organelles.

Of the remaining candidate reference genes, Act, GAPDH, $U B C, W A R S, S D H$ and TBP had a constant expression following exposure to IB. But although, GAPDH and UBC were the most stable reference genes they both had a weakly significant $(p<0.10)$ linear trend of down-regulation. Thus, relying solely on either of these two reference genes for normalisation could obscure the output.

Using reference genes as an internal control in QPCR is currently the recommended approach [5]. However, Bustin and Nolan, 2004 [21] advocate the introduction of more standard analysis and reporting procedures in QPCR similar to the MIAME guidelines [22] established for microarray technology. In union with other authors $[5,10,21,23]$ we would like to recommend some basic applications for QPCR: (i) apply a dissociation curve in every QPCR, and omit any samples diverging from the curve; (ii) use a minimum of two non-template controls (NTCs) in every QPCR, and omit any samples having a cycle threshold $\left(\mathrm{C}_{\mathrm{t}}\right)$ value close to or higher than the mean NTC $\mathrm{C}_{\mathrm{t}}$-value; (iii) avoid inter-assay comparison if possible, as it is more appropriate to duplicate the samples in one QPCR than using triplicates of each sample, but having to run two QPCRs (S.N. Peirson, personal communication); (iv) use a NF based on a minimum of three validated reference genes for target gene normalisation [10]; (v) integrating the DART-PCR approach [23], which verifies sample-to-sample variations in amplification efficiency with a normalisation factor software package, e.g. geNorm [10], creates a powerful tool for analysing relative gene expression of target genes.

\section{Conclusions}

Investigators engaging in toxicogenomic research using invertebrates, or vertebrate cell lines, exposed to NSAIDs may be able to apply our findings directly under similar experimental conditions, e.g. acute exposure. However, we strongly recommend validating reference genes prior to commencing target gene expression profiling under experimental conditions different than those described herein. Our findings stress the importance of performing fundamental research, by validating the most invariant internal QPCR control(s) of a particular experimental condition, prior to investigating the expression of target genes examined by QPCR only, or as QPCR validation of microarray data.

\section{Methods \\ Test species}

Daphnia magna Straus (Clone Type 5 - IRCHA), originally obtained from the Water Research Centre (WRc), Medmenham, UK, were investigated. For further information on culturing conditions of D. magna please see Hooper et al., 2006 [24].

\section{Experimental design and analytical chemistry}

The experimental design consisted of three replicates of a control and three treatments with ibuprofen-sodium (Sigma-Aldrich, CAS no. 31121-93-4) containing 20, 40 and $80 \mathrm{mg} \mathrm{IB} \mathrm{l}^{-1}$, respectively. Each replicate consisted of 100 third brood neonates $(<24 \mathrm{~h}$ old $)$ placed in a 1000 $\mathrm{ml}$ glass beaker containing one litre of reconstituted freshwater with or without the addition of IB. Neonates were exposed to IB for $24 \mathrm{~h}$ under the same conditions as stock cultures (see Hooper et al., 2006 [24]), but without feeding. To quantify IB, $1.5 \mathrm{ml}$ was sampled from each replicate at $0 \mathrm{~h}$ and $24 \mathrm{~h}$ and stored at $-20^{\circ} \mathrm{C}$. Subsequently, the free base concentration of IB was measured at $217 \mathrm{~nm}$ by UV-spectrophotometry using an Ultrospec 3000 (Biochrom) after the method of Pascoe et al., 2003 [25]. Conductivity, $\mathrm{pH}$ and water temperature were checked at the beginning and at the end of the exposure to verify stable water chemistry.

\section{Tissue preparation, RNA extraction and reverse transcription}

Following exposure, the neonates were immediately placed in $0.2 \mathrm{ml}$ of RNAlater (Ambion) and stored at $80^{\circ} \mathrm{C}$. Subsequently, total RNA was extracted using the RNeasy Mini kit with on-column DNase treatment (Qia- 
gen) to remove any traces of genomic DNA following the manufacturer's instructions. RNA concentrations were determined by spectrophotometry using GeneQuant Pro (Biochrom). The integrity of the RNA was verified by $1 \%$ agarose gel electrophoresis. Four micrograms of DNasetreated total RNA was reverse transcribed with Oligo(dT) $)_{12-18}$ primers (Invitrogen) using the Omniscript Reverse Transcriptase kit (Qiagen) following the manufacturer's instructions. Once synthesised, cDNA was diluted 10 -fold resulting in total RNA concentrations of $10 \mathrm{ng} / \mu \mathrm{l}$ and stored at $-20^{\circ} \mathrm{C}$.

\section{Real-time quantitative $\mathbf{P C R}$}

Ten expressed sequence tags (ESTs) were obtained from the NCBI website [26] and the Daphnia Genomics Consortium website [27] (see Colbourne et al., 2005 [28]). ESTs were verified by BLASTN and BLASTX analysis [26]. Primers were designed using Primer3 [29], and synthesised by MWG. The investigated ESTs, accession numbers, primer sequences and gene ontology are shown in Table 1.

QPCR was conducted on the GeneAmp 5700 Sequence Detection System (SDS) (Applied Biosystems) using ABsolute $^{\mathrm{TM}}$ QPCR SYBR ${ }^{\circledast}$ Green ROX (500 nM) mix (ABgene). Each reaction was run in triplicate and contained $2.5 \mu \mathrm{l}$ of cDNA template (equivalent to $25 \mathrm{ng}$ total RNA) along with $900 \mathrm{nM}$ primers in a final volume of 25 $\mu \mathrm{l}$. Cycling parameters were $95^{\circ} \mathrm{C}$ for 15 min to activate the DNA polymerase, then 40 cycles of $95^{\circ} \mathrm{C}$ for $15 \mathrm{~s}$ and $60^{\circ} \mathrm{C}$ for $1 \mathrm{~min}$. Melting curves were performed by using dissociation curve SDS software version 1.3 (Applied Biosystems) to verify that only a single product with no primer-dimers were amplified.

\section{Data analysis and statistics}

Following QPCR, the raw data was exported to an Excel workbook (Microsoft), entitled Data Analysis for RealTime PCR (DART-PCR) [23]. This programmed workbook enables calculation of threshold cycles and amplification efficiencies for every sample. Differences in amplification efficiency were assessed using one-way analysis of variance (ANOVA), based upon the null hypotheses: (i) that amplification efficiency is comparable within sample groups (outlier detection) and (ii) that amplification efficiency is comparable between sample groups (amplification equivalence) [23]. Outliers identified by DART-PCR and samples diverging from the dissociation curve were omitted prior to further analysis.

Differences in relative expression were assessed on logtransformed data using ANOVA and Tukey's honestly significant difference (HSD) for post hoc comparisons. Equality of variance was tested using Levene's test. The relative expression of the reference genes calculated by DART-PCR was exported as an Excel workbook (Micro- soft) to geNorm version 3.4 [10]. The "geNorm" algorithm is based on the proposition that, in any set of assays, the expression levels of suitable reference genes should be perfectly correlated. However, because of technical difficulties in assessing correlation in circumstances when there is little variation, a modified procedure is adopted as follows [10]. First, the ratio of expression levels is calculated for any two candidate reference genes. Assuming that the expression ratios should not vary between assays, the variation between the expression ratios is used as an inverse measure, here referred to as gene variability, of the adequacy of the reference genes to be used for normalisation. Thus, the lower the variation, the better the reference genes. Variation is here measured as standard deviation. Given a set of assays that covers the treatments of interest, this procedure can be used to identify the best two reference genes from all possible pairs of reference genes available to the experimenter. A normalisation factor $\left(\mathrm{NF}_{2}\right)$ is then produced for these two genes, calculated as the geometric mean of their expression levels. The procedure is then extended to assess whether stepwise inclusion of additional reference genes - producing $N F_{3}$ to $N F_{n}$ - will reduce the average pairwise variation between them. The optimal number of reference genes to be included in a NF is estimated by comparing the pairwise variation between sequential normalisation factors [10], e.g. $\mathrm{NF}_{3} \mathrm{vs} . \mathrm{NF}_{4}$. All statistical tests were performed in SPSS 12.0.1 for Windows (SPSS, Chicago, IL, USA) applying a significant level of $5 \%$, except reference gene variability and NF analysis, which was computed in geNorm version 3.4 [10].

\section{Authors' contributions}

All authors participated in the coordination and design of the study. LHH performed all the practical aspects of the study (i.e. exposure of D. magna and genomic analyses) under the supervision of AC and RC. Furthermore, LHH performed the statistical analyses under supervision of RMS, and drafted the manuscript. All authors read, contributed intellectually and approved the final manuscript.

\section{Acknowledgements}

We gratefully acknowledge the financial support of AstraZeneca, Syngenta, NERC (project NER/D/S/2002/004I 3 "The population and molecular stress responses of an ecotoxicology indicator species") and The Research Endowment Trust Fund of The University of Reading. Furthermore, we are thankful to Dr Stuart N. Peirson and Dr Godfrina Mckoy for valuable discussions on QPCR, and three anonymous reviewers for their valuable comments on the manuscript.

\section{References}

I. Orphanides G: Toxicogenomics: challenges and opportunities. Toxicol Lett 2003, I40-141: | 45- | 48.

2. Dallas PB, Gottardo NG, Firth MJ, Beesley AH, Hoffmann K, Terry PA, Treitas JR, Boag JM, Cummings AJ, Kees UR: Gene expression levels assessed by oligonucleotide microarray analysis and quantitative real-time RT-PCR - how well do they correlate? BMC Genomics 2005, 6:59. 
3. Bustin SA: Absolute quantification of mRNA using real-time reverse transcription polymerase chain reaction assays. J Mol Endocrinol 2000, 25:169-193.

4. Williams TD, Gensberg K, Minchin SD, Chipman JK: A DNA expression array to detect toxic stress response in European flounder (Platichthys flesus). Aquat Toxicol 2003, 65:|4|-157.

5. Huggett J, Dheda K, Bustin S, Zumla A: Real-time RT-PCR normalisation; strategies and considerations. Genes Immun 2005, 6:279-284.

6. Thellin O, Zorzi W, Lakaye B, De Borman B, Coumans B, Hennen G, Grisar $T$, lgout $A$, Heinen $E$ : Housekeeping genes as internal standards: use and limits. J Biotech 1999, 75:291-295.

7. Radonic A, Thulke S, Mackay IM, Landt O, Siegert W, Nitsche A: Guideline to reference gene selection for quantitative realtime PCR. Biochem Biophys Res Commun 2004, 3 I 3:856-862.

8. Bustin SA: Quantification of mRNA using real-time reverse transcription PCR (RT-PCR): trends and problems. J Mol Endocrinol 2002, 29:23-39.

9. Pfaffl MW, Tichopad A, Prgomet C, Neuvians TP: Determination of stable housekeeping genes, differentially regulated target genes and sample integrity: BestKeeper - Excel-based tool using pair-wise correlations. Biotechnol Lett 2004, 26:509-5I5.

10. Vandesompele J, De Preter K, Pattyn F, Poppe B, Van Roy N, De Paepe A, Speleman F: Accurate normalization of real-time quantitative RT-PCR data by geometric averaging of multiple internal control genes. Genome Biol 2002, 3:research0034.I-0034.II.

II. geNorm software [http://medgen.ugent.be/ jivdesomp/genorm/]

12. BestKeeper software [http://www.gene-quantification.info/]

13. Heckmann LH, Connon R, Hooper HL, Maund SJ, Hutchinson TH, Sibly RM, Callaghan A: Molecular and population stress responses of Daphnia magna exposed to ibuprofen [abstract]. In Society of Environmental Toxicology and Chemistry Europe 15th Annual Meeting, Lille, France:308. 22-26 May 2005

14. Coulson CJ: Molecular Mechanisms of Drug Action. London: Taylor and Francis; 1994.

15. Stanley-Samuelson DW: Assessing the significance of prostaglandins and other eicosanoids in insect physiology. J Insect Physiol 1994, 40:3-II.

16. Rowley AE, Vogan CL, Taylor GW, Clare AS: Prostaglandins in non-insectan invertebrates: recent insights and unsolved problems. J Exp Biol 2005, 208:3-|4.

17. Tucker CL, Fields S: Quantitative genome-wide analysis of yeast deletion strain sensitivities to oxidative and chemical stress. Comp Func Genomics 2004, 5:21 6-224.

18. Kim KS, Yoon JH, Kim JK, Baek SJ, Eling TE, Lee WJ, Ryu JH, Lee JG, Lee JH, Yoo JB: Cyclooxygenase inhibitors induce apoptosis in oral cavity cancer cells by increased expression of nonsteroidal anti-inflammatory drug-activated gene. Biochem Biophys Res Commun 2004, 325: 1298-1303.

19. English N, Hughes V, Wolf GR: Induction of cytochrome P450(BM-3) (CYP 102) by non-steroidal anti-inflammatory drugs in Bacillus megaterium. Biochem J 1996, 3 16:279-283.

20. Tarnawski AS, Jones MK: Inhibition of angiogenesis by NSAIDs: molecular mechanisms and clinical implications. J Mol Med 2003, 81:627-636.

21. Bustin SA, Nolan T: Pitfalls of quantitative real-time reversetranscription polymerase chain reaction. J Biomol Tech 2004, 15:155-166.

22. MIAME [http://www.mged.org/miame]

23. Peirson SN, Butler JN, Foster RG: Experimental validation of novel and conventional approaches to quantitative real-time PCR data analysis. Nucl Acids Res 2003, 31 :e73.

24. Hooper HL, Connon R, Callaghan A, Maund SJ, Liess M, Duquesne S, Hutchinson TH, Moggs J, Sibly RM: The use of image analysis methods to estimate population growth rate in Daphnia magna. J Appl Ecol 2006 in press.

25. Pascoe D, Karntanut W, Muller CT: Do pharmaceuticals affect freshwater invertebrates? A study with the cnidarian Hydra vulgaris. Chemosphere 2003, 51:52I-528.

26. NCBI [http://www.ncbi.nlm.nih.gov/]

27. wFleaBase [http://wfleabase.org/]

28. Colbourne JK, Singan VR, Gilbert DG: wFleaBase: The Daphnia genome database. BMC Bioinformatics 2005, 6:45.

\begin{tabular}{l} 
29. Primer3 software [http://frodo.wi.mit.edu/cgi-bin/primer3/ \\
\hline
\end{tabular} primer3 www.cgi]
Publish with Biomed Central and every scientist can read your work free of charge

"BioMed Central will be the most significant development for disseminating the results of biomedical research in our lifetime. "

Sir Paul Nurse, Cancer Research UK

Your research papers will be:

- available free of charge to the entire biomedical community

- peer reviewed and published immediately upon acceptance

- cited in PubMed and archived on PubMed Central

- yours - you keep the copyright

Submit your manuscript here:

http://www.biomedcentral.com/info/publishing_adv.asp 